\title{
Rosa M. CAlCATERRA (ed.) New Perspectives on \\ Pragmatism and Analytic Philosophy
}

Amsterdam-New York, Rodopi, 2001

\section{Anna Boncompagni}

\section{(2) OpenEdition}

Electronic version

URL: http://journals.openedition.org/ejpap/854

DOI: 10.4000/ejpap.854

ISSN: 2036-4091

\section{Publisher}

Associazione Pragma

Electronic reference

Anna Boncompagni, «Rosa M. calcaterra (ed.) New Perspectives on Pragmatism and Analytic Philosophy », European Journal of Pragmatism and American Philosophy [Online], III-2 | 2011, Online since 29 December 2011, connection on 24 September 2020. URL : http://journals.openedition.org/ejpap/854 ; DOI : https://doi.org/10.4000/ejpap.854

This text was automatically generated on 24 September 2020

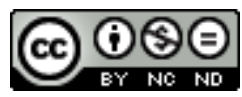

Author retains copyright and grants the European Journal of Pragmatism and American Philosophy right of first publication with the work simultaneously licensed under a Creative Commons AttributionNonCommercial-NoDerivatives 4.0 International License. 


\section{Rosa M. CAlCATERra (ed.) New Perspectives on Pragmatism and Analytic Philosophy}

Amsterdam-New York, Rodopi, 2001

\section{Anna Boncompagni}

\section{REFERENCES}

Rosa M. CALCATERRa (ed.) New Perspectives on Pragmatism and Analytic Philosophy, AmsterdamNew York, Rodopi, 2001

\section{Introduction and Historical Framework}

1 Pragmatism and analytic philosophy are two very complex and ramified schools of thought, two ways of conceiving the philosophical work, both of which extremely hard to define in a satisfactory and shared manner. For this reason, the attempt to make a study of their relations and interactions, encounters and clashes, may seem even more risky and uncertain. But New Perspectives on Pragmatism and Analytic Philosophy (Rodopi 2011), edited by Rosa Calcaterra, shows that on the opposite it is exactly through this comparison, built from different points of views, that we can gain a fresh and deep understanding of both of them. The volume offers an investigation that works on an historical and theoretical standpoint at once. It collects contributions by Vincent Colapietro, Mario De Caro, Rossella Fabbrichesi, Maurizio Ferraris, Nathan Houser, Ivo Assad Ibri, Giovanni Maddalena, Michele Marsonet, John McDowell and Eva Picardi, all of which show that the dialogue between the two schools has proven and proves to be surprisingly fruitful, not only in highlighting the main characteristics of the two interlocutors, but also in putting on the foreground new ways of conceiving traditional themes. It is indeed now almost impossible to catch the key features of neopragmatism 
without reference to the analytic tradition, and, on the other hand, it is almost impossible to understand the key features of post-positivist analytic philosophy without reference to the revival of some traditional pragmatist themes.

Rosa Calcaterra's "Introduction" provides a useful framework which contextualizes the recent developments of research in the historical roots of the relation between classical pragmatism and analytic philosophy, both in the United States and in Europe. Pragmatism dominated the American academic scene until the arrival of the most prominent representatives of the Vienna Circle from Europe, who first interacted with, and later ousted the pragmatists from what was considered "serious" philosophical work, seeing them as lacking the necessary logical and epistemological rigor. In Europe, too, pragmatism had to face numerous critiques, and it almost disappeared during the establishment of the new currents of phenomenology, Marxism and hermeneutics. It was in the Sixties that in both contexts, US and Europe, pragmatism was revitalized, as it could easily become an allied of new perspectives centered on practical philosophy and concerned with the problems of action, fallibilism, and the relation between objectivity and intersubjectivity. What can be traced is a sort of double movement, aiming at the revision of the neoempirist epistemological paradigm on the one hand, and at the reinstatement of the pragmatist method in the context of the contemporary world and philosophical debate, on the other. Calcaterra focuses on some key figures of what has been called the pragmatic turn in contemporary thought: Otto Apel and Jürgen Habermas, Hilary Putnam, Richard Rorty, Willard Quine, Wilfrid Sellars, Donald Davidson. Apel and Habermas' pragmatic version of normativity is explicitly reminiscent of Peirce (mostly for Apel) and Mead (mostly for Habermas), and their shift from subjectivity to the new paradigm of intersubjectivity parallels the developments of the philosophy of ordinary language worked out by Austin and Searle, so that the linguistic turn and the pragmatic turn can be read as two aspects of the same phenomenon. Putnam's and Rorty's different interpretations of pragmatism reflect two different ways of thinking about a crucial issue like truth: in Putnam's view, it is a limiting concept that allows a progressive move towards factual reality, while in Rorty it is transferred into a hermeneutic and historicist context, that leads to the acknowledgment of the social, linguistic, cultural nature of reality itself. Quine, Sellars and Davidson, finally, can be read, as Calcaterra proposes, as not abandoning but reformulating realism, so that the interference between the logical and empirical dimension implies a concept of truth which cannot be reduced to sense-data, but entails a more sophisticated form of correspondentism, where naturalism and the criterion of intersubjectivity can interact. The search for new criterions for objectivity is probably one of the most important, but not the only, issue on which this dialogue is not only promising, but also needed.

3 This is also underlined by Michele Marsonet, who in his "Different Pragmatist Reactions to Analytic Philosophy" adds some historical notes. Pragmatism and analytic philosophy - he affirms - share many similarities, such as the interest in scientific results and methods and the request that philosophers give serious reasons in support of their assertions, aspects which can be traced back to the key role that intersubjectivity plays in both traditions. This has undoubtedly been fundamental in the initial encounter between them. Later, Marsonet says, neopositivists endorsed scientism while pragmatists did not, as they denied the existence of one and only one true method to be adopted both by science and philosophy. This historical frame is 
what enables Marsonet to introduce the not so well-known figure of Nicholas Rescher, whose originality is often neglected. He compares Rescher with Quine, Sellars and Rorty, portraying his pragmatic idealism as rooted in evolutionism and in a new and sometimes problematic account of the relation between factual and logical truths as well as between subject and object. In the distance between Rescher and Rorty, particularly, he sees a continuation of the difference between the objective pragmatism as defined by Peirce and Lewis (and Rescher) and the subjective pragmatism represented by James and the early Dewey (and Rorty). He concludes that the end of philosophy prophesized by Rorty is inevitably considered by Rescher a wrong answer to the acknowledgment that philosophy cannot detach itself from history; on the opposite, philosophical activity, as a sort of "intellectual accommodation," is requested in our everyday life at least as much as physical accommodation.

4 Turning from the historical to the more theoretical issues, the relation between pragmatism and analytic philosophy rotates around some main themes, which can be used as guides to give an idea of the different points of view that are expressed in the single essays. These themes can be individuated as couples of entangled concepts: naturalism and scientism; facts and values; actions and practices; perception and meaning; truth and realism. We can thus deal with some aspect of the different contributions by means of dealing with these main concepts, avoiding a plain description of the single essays in order to privilege a more unified and dialogical reasoning.

\section{Naturalism and Scientism}

5 According to Marsonet, as we have just seen, the first big divide between analytics and pragmatists was that the former endorsed scientism, the latter refused it in the name of methodological pluralism. Between the two world wars the move towards the rigor of scientific discourse had success, but later on, when the underground influence of pragmatism came more openly to the surface, the entanglement between science and ethics and the impossibility of a perfectly neutral scientific method were more commonly acknowledged. Also, we could add, what was going on in the field of philosophy of science, with Thomas Kuhn and Paul Feyerabend, was not that distant from these perspectives. But what sort of relation can be drawn between scientism and naturalism, considered that naturalism was, differently from scientism, usually supported by the pragmatist scholars? A clarifying contribution in this direction comes from Mario De Caro's essay, "Beyond Scientism," that aims to define and distinguish scientism, scientific naturalism and other forms of naturalism. Scientific naturalism, as it is ordinarily described by its supporters, De Caro argues, can be characterized by three main claims: the constitutive thesis, for which philosophy does not admit any supernatural entity; the antifoundationalist thesis, for which there is no such thing as a "first philosophy"; the continuity thesis, for which philosophy must be a partner of science. But scientific naturalism thus conceived can be criticized for different reasons. One of these is that it often idealizes contemporary science describing it as methodologically and ontologically unified, where it is not; here, again, we meet methodological pluralism as a (pragmatist) opponent to scientism, similarly to what we found in Marsonet. De Caro espouses a weaker version of the three premises of scientific naturalism, and pointing towards what here and elsewhere he calls liberal or 
liberalized naturalism, ${ }^{1}$ he agrees with many issues of pragmatism, such as, for example, the compatibility but not the reduction of philosophy to scientific theories, and the insistence that values and facts can hardly be detached from each other. What this description leaves open to a further analysis, is how pragmatism itself can be studied as proposing not one single form, but different forms of naturalism, in connection with the different ideas of science that its representatives held. It could indeed be interesting to go beyond an abstract identification of the characteristics of scientism and naturalism, to investigate whether and how classical and contemporary pragmatists in their writings concretely used a naturalistic, but not scientistic, view of the world.

\section{Facts and Values}

6 As regards the entanglement between facts and values, which we have just mentioned, two other essays contained in Calcaterra's volume have to be considered: Rossella Fabbrichesi's "The Entanglement of Ethics and Logic in Peirce's Pragmatism" and Giovanni Maddalena's "Wittgenstein, Dewey and Peirce on Ethics," which share an interest in Peirce's ethics and in its connection with logic and the hierarchy of sciences. Fabbrichesi traces back Putnam's idea of the entanglement between facts and values to Peirce's normativity of logic. Putnam, criticizing how neopositivist and analytic philosophers often attempted to keep rigidly separated facts and values, points out that the ideals of scientific and theoretical research are implicitly ethic, in their preferring consistency, simplicity, plausibility, order; and notes that pragmatism already had affirmed that in every acknowledgment of a "pure fact" there is a value judgment. Peirce includes logic, together with ethics and aesthetics, in the normative sciences and this inclusion is the reflection of his idea of pragmatic meaning. Fabbrichesi's paper focuses then on Peirce's "future-tense conception" of interpretation and inference and on the bond between this ethical commitment and the public nature of truth, linking it to the dialectic between the particular and the general. As regards Maddalena, his starting point is a question: is Rorty right in affirming the surrender of philosophy to literature and to politics, on the grounds of the ineluctable gap between what is normative and what is real? He first examines Wittgenstein and Dewey's accounts of ethics (the two philosophers that Rorty mainly refers to), and then proposes Peirce's theory as a way out that permits to avoid Rorty's conclusion. Wittgenstein, in the Tractatus and in the 1929 Conference on ethics, ${ }^{2}$ considers ethics as a view of the world, and then as a phenomenological experience, but not as a science of behavior. In the Philosophical Investigations, ${ }^{3}$ the absolute value has lost its absoluteness and is now embodied in use and in life, but again we cannot make of ethics a science. What is normative and what is real are separate. In Dewey, there is an apparent unity of thought and practice, consciousness and reality, but if we look at his philosophy more accurately, according to Maddalena, we see that dualism is both the starting point of his analysis of moral theory (desire and thought), ${ }^{4}$ and the always present risk of its conclusion, because in social values we can see a double aspect: private satisfaction and public utility (Maddalena, 90). So in Dewey too we cannot say that what is normative and what is real are really unite. On the contrary, if we consider Peirce's view and particularly his semiotics and his classification of sciences, we find a final unity. Ethics indeed is inserted in a hierarchy of sciences, it has a precise role in knowledge and 
continuity among sciences is a reality: this is what could prevent Rorty from drawing his dualistic conclusion.

7 Fabbrichesi and Maddalena's insights seem to converge on the relevance of the continuity between logic, science and ethics, though their perspective do not perfectly overlap. In the latter's case, with reference to Wittgenstein, it is said that if we cannot make of ethics a science, it means that ethics and reality are separate. But we could work also in the opposite direction, and ask ourselves whether science has not in itself already an ethical dimension. In the later Wittgenstein we may find exactly this suggestion, that is, the idea that any description of reality is part of a Weltbild and has a normative dimension. Thus, it is not only in Peirce, but also in Wittgenstein, that we could find the entanglement between facts and values and between logic and ethics. Furthermore, going back to Fabbrichesi's analysis of the public dimension of inference and truth, new elements for a useful comparison could be found in Wittgenstein's treatment of following a rule and of the impossibility of a private language.

\section{Actions and Practices}

8 Vincent Colapietro's contribution ("Allowing our Practices to Speak for Themselves") goes in this direction, comparing Wittgenstein and Peirce on rules and practices and challenging the traditional view according to which Wittgenstein's so-called quietism is at odds with the pragmatists' meliorism. The centrality of practices and the later Wittgenstein's work to clarify what they are, how they function, which is our place inside them, in Colapietro's opinion still needs to be appreciated by pragmatists. Practices are not decided by rules and rules are not fixed; we learn to follow rules in familiar and social contexts, with other people as teachers and judges, we learn by doing and do by learning. We are compelled but also free in the same time, so that our practices must be granted the opportunity to speak for themselves.

9 An interesting connection can be drawn here with John McDowell's characterization (in his "Pragmatism and Intention-in-Action," still in this volume) of the pragmatist idea of action as an exercise of a skill, manifesting a practical intelligence, a conception that avoids commitment to the Cartesian image of thought as something happening in a separated inner realm. The relation that, following Colapietro, we can establish between a practice and its rule, parallels the relation that, following McDowell, we can establish between an action and its intentional content. Just like practice embodies a rule, and does not simply apply it, action embodies an intention, and does not simply apply it. There is no gap between practice and rule, nor between action and intention. McDowell particularly examines Sellars' and Brandom's models for intention-in-action and concludes that none of the two truly respect the pragmatist conception of action, because they both remain anchored to the idea that action is something that comes after thought. Starting from Sellars, who actually does not conceive his proposal as a variety of pragmatism, McDowell argues that he thinks of unexpressed thought on the model of speech, and of linguistic practices as language games. ${ }^{5} \mathrm{He}$ distinguishes three moves in language games: those starting from outside the game and finishing inside it (language-entry transitions, like reports of perceptions), those within the game (intralinguistic transitions, inferences) and those starting from language and finishing in action (language-exit transitions); practical reasoning in this model is precisely what constitutes the starting point for actions. In this way, actions are conceived as exits 
from the sphere of the conceptual, and this can hardly accord with the pragmatist idea of thought as present in behavior and not separable from behavior. Brandom, on the other hand, ${ }^{6}$ who explicitly declares his theory to be pragmatist, applies the Sellarsian vision of actions as exits only in connection with intentions for the future, and characterizes intentions-in-actions in a strict sense according to an idea of action as acknowledging a commitment. But conceiving practical commitments as dispositions to say "yes" to an action, in McDowell's reading, Brandom, too, thinks about intention-inaction as a response to something (this is what an assent is), and thus not really "in" action, but separate from it. For this reason, according to McDowell, neither Sellars nor Brandom have caught the pragmatist intuition of conceiving intention-in-action as a practical skill to be found within the action itself.

It may be, then and again, in Wittgenstein's idea of practices, read through Colapietro's lenses, that such an account could find a good interlocutor. Following, among others, Stanley Cavell and Naomi Scheman, ${ }^{7}$ Colapietro also helps us to see in Wittgenstein both the search for the ordinary and the escape from the ordinary, so that human practices are at the same time our home and our prison, and we are called not only to acknowledge our traditions - what has usually been associated with Wittgenstein - but also to acknowledge that our home is always an exile. In this light, Colapietro invites us not to forget the polemic and critical aspect of many of Wittgenstein's remarks, which is often misrepresented and which, once seen, can be considered another point of convergence with pragmatism.

\section{Perception and Meaning}

11 The theme of intention-in-action leads us into another set of correlated concepts, such as those of perception, conceptual content, representation, meaning, and more generally the relation between mind and world, to remain in a McDowellian framework. ${ }^{8}$ Nathan Houser ("Action and representation in Peirce's pragmatism"), stating the difficulty of defining both analytic philosophy and pragmatism, explores the possibility of a dialogue between these two "family resembles" schools of thought by applying Peirce's idea of perception and of experience to the problem of the relation between mind and world, as addressed by McDowell. Indeed, Peirce's concept of thought as answerable to the world and at the same time instrumental in the course of events, seems to fit perfectly in McDowell's dilemma of how thought (which is normative) can be tested in "the tribunal of experience" (which is natural). Normative thought, that is, all thought - Peirce would agree with McDowell on this - belongs to the logical space of reason; therefore, how can experience be a valid test or tribunal for it? Can we prove our concepts to be correct if experience is conceived as exclusively sensory and not conceptual? This is where Peirce's ideas of perception, experience, knowledge can be of help. Houser focuses on this well-known passage by Peirce: "The elements of every concept enter into logical thought at the gate of perception and make their exit at the gate of purposive action; and whatever cannot show its passports at both those two gates is to be arrested as unauthorized by reason." In perception, Peirce sees two elements: the percept, which "forces upon us" and is absolutely dumb; and the perceptual judgment, that professes to represent the percept, and belongs to the logical space of reasons. What is the bridge between the two? It is - Houser argues a virtually unconscious "proto-abductive inference that relies more on instinct than on 
reason" (Houser, 67). The point is that these perceptual judgments are to be checked not by a backwards appeal to sensory experience, but by experiences to come, so that our conduct, the outcome of thought, will be justified or falsified by future experience. In this way, experience do indeed serve as a tribunal for the reliability of conceived consequences. Whether this reference to the future, and the enlargement of the concept of experience that is so pointed out, meets the need for a reconciliation between the two reigns of sensibility and intellect, and whether this accords or not with McDowell's own solution of the problem, is surely a matter worth working on in still more detail.

12 Another essay that focuses on the relation between mind and world is Eva Picardi's "Pragmatism as anti-representationalism?," which is particularly centered on the nature of thought and on whether it is true or not that, as Rorty affirms,$^{10}$ pragmatism conceives it as inferentional and not representational. In Rorty's view, representationalism leads to relativism, because, as Donald Davidson has shown, ${ }^{11}$ any representation is relative to a scheme. Although some representationalist's central issues - such as that "thinking at" is prior to "thinking that" and that a given sentences has always a definite meaning - are too stark, in Picardi's opinion their critiques to representationalism are not always wrong; for example when they point out that for inferentialists it is difficult to explain the compositionality of meaning. Picardi's conclusion is that Rorty's idea of anti-representationalism as a univocally positive characteristic of pragmatism is over simplified. Anti-representationalism is not always a feature of pragmatism, neither old nor new, and it is not always a merit; representationalism itself, though purified from some of its questionable tenets, can be useful for good theories of meaning and of thought. Thus, in Picardi's articulated work, the relation between pragmatism and analytic philosophy appears to be much more complex that any simple account could represent.

\section{Truth and Realism}

13 The last couple of themes with which we can close our review is the most general and, probably, the one on which there has been the highest number of misunderstandings in the history of pragmatism: the concept of truth and the idea of realism that it entails. The two essays which will help us to clarify the matter are Maurizio Ferraris' "Indiana James" and Ivo Assad Ibri's "Semiotics and Epistemology: The Pragmatic Ground of Communication"; the former is linked to the traditional early-analytic critique that Bertrand Russell moved to the pragmatist conception of truth, the latter develops what we can call a semiotic conception of reality. Ferraris' aim is to investigate James' theory of truth relating it to the problem of ontology, thus also clarifying Russell's criticism towards him. James' theory of truth is baptized by Russell "Transatlantic Truth" 12 and is identified with this definition: "True ideas are those that we can assimilate, validate, corroborate and verify." ${ }^{13}$ Ferraris takes this to mean that truth is what is convenient for us to believe, and on the basis of this he confronts James' positive attitude towards the existence of God with his (James') negative attitude towards the hypothesis of the "Automatic Sweetheart," a soulless body indistinguishable from a lovely human being (an example famously discussed also by Hilary Putnam ${ }^{14}$ ). If truth is what is convenient for us to believe - asks Ferraris - why shouldn't we believe in the Automatic Sweetheart? The answer is that, in refusing to believe this, James is actually accepting 
the corrispondentist theory of truth, or what Ferraris calls the "Pacific Truth." Pacific Truth is committed to ontology, that is, to the idea that objects are what resists our will, and in refusing the Automatic Sweetheart - this is Ferraris' diagnosis - James is revealing never to have abandoned this idea. In Ferraris opinion, this shows that Russell and James were not talking about the same thing: Russell was concerned with ontology, James with epistemology, or - at best - with a theory of scientific knowledge. Unfortunately, Ferraris relegates James' reformulation of the criterion of correspondence to a footnote (Ferraris, 58), and in so doing he probably misses the point of a serious reconsideration of what is at stake. Evidently Ferraris assumes that only a strong commitment with an ontologically based theory of truth allows the hypothesis of knowing what is true and what is not. But this seems to be the premise, as much as the conclusion, of his argument. Let us consider James' words about correspondence, even limiting our investigation to the short passage cited by Ferraris: to agree with reality is "to be guided" towards it or "to be put onto a working touch with it as to handle it [...] better than if we disagreed." 15 Ferraris considers this definition as "not very convincing," but reading through James' undoubtedly vague words we can foresee an idea of correspondence in which the direction ("to be guided") and the skill or the ability to do something ("to handle it better") are key features. It is here that the last essay which we are considering can be of help. Ivo Ibri ("Semiotics and Epistemology: the Pragmatic Ground of Communication"), working not on James but on Peirce, proposes an idea of reality according to which the world is, by itself, meaningful. That is: language is not the creator of sense, but a mere representative of sense, whereas meanings are already in the world and in its natural signs. Perceiving the natural signs contained in the world, we are guided by them, as James suggested, so that a Peircean semiotic conception of reality can be put directly in relation to James' "Transatlantic Truth." Realism and semiotics in Peirce are linked with his complex philosophical system: Ibri's essay offers an interesting reading, that we can sum up in the expression "semiotic realism." Peirce's three categories and his vision of a symmetry between subject and object are the starting points of Ibri's argument, that at its very beginning needs to face a seemingly unavoidable circularity: on the one hand, realism seems the necessary ground for semiotics and logic, and, on the other, if we want to read signs in reality, semiotics must shape the ground for realism itself. It is indeed the symmetry between subject and object, phenomenologically understood as modes of being, that permits to avoid circularity acknowledging that their respective structure is the same, and knowledge is materialized in the universal forms of objects. But this leads us beyond language, because reality does not manifest its segnic quality only by linguistic concepts. In other words, we must acknowledge a semiotic nature also to each natural and human occurrence. For this to be possible, there has to be a continuity between experience and concept, and this is what is meant by Peirce's idealism of objective content, that does not conflict with, but rather strengthen, his realism. Peirce's logic, read through the lenses of his realism, allows a wider conception of semiotics that concerns not only language but the world itself, characterized by a meaningful nature.

14 The link between Ibri's reading and the issue raised by Houser, regarding mind and world and the conceptual nature of perception, is, I think, clear, and it is clear that, according to this reading, the idea of truth that pragmatism entails is not confined to epistemology but has deep ontological consequences. This evidently contrasts Ferraris' "new realist" conception of truth and his interpretation of James, and highlights 
ontology as one of the main themes on which the dialogue between pragmatists and analytics still has much to say.

\section{Two More Suggestions and a Conclusion}

15 Finally, it must be mentioned that the Italian edition of the volume ${ }^{16}$ also includes two more essays, by Rosa Calcaterra and by Damiano Canale and Giovanni Tuzet: they were unfortunately left out of the English edition due to technical reasons, but it is nevertheless much worth devoting some words to them too. Calcaterra's essay particularly can be connected to the debate on realism: it deals with James' conception of truth as it is seen by Hilary Putnam. The intertwinement among truth, utility and reality that characterizes James' position and his adoption of truth as a regulative ideal are central for Putnam's reflection on internal realism and for his proposal of truth as an idealization of warranted assertability. The dimension of collectivity is here introduced as another mainstay of realism, and, again, the dialogue between pragmatist and analytic traditions confirms to be the most current and topical: Ferraris' "new realism" and his work on documentality, but also John Searle's social ontology, owe much to the acknowledgement of the relevance of this collective dimension in the building of reality itself. Another interesting comparison is presentend in Canale and Tuzet's essay, which confronts Peirce, Searle and Brandom on the theory of assertion, particularly focusing on the kind of commitment and responsibility that an assertion entails: does it commit the speaker to the truth of what he asserts, or to the sincerity of his words? The most interesting position is here that of Brandom, whose starting point is the social practice of attributing and acknowledging beliefs to the speakers on the basis of their assertions. Adopting this typical pragmatist criterion, he is able to overcome the limits of a conception of belief based on mental states, and to work on what in Peirce had remained implicit, that is, the distinction between two kind of inferences: one going from the assertion to the beliefs, which commits the speaker to sincerity; the other going from the assertion to its practical consequences, which commits the speaker to the truth of what he says.

To sum up and conclude, the essays collected in Calcaterra's volume are excellent examples of how the two traditions of pragmatism and analytic philosophy, when working together, are able to clarify their own identities and to produce new and sometimes unexpected results. Furthermore, it is worth noticing how the different attitudes expressed in the essays are reflected in different interpretations that the authors give of some key figures. For example, Colapietro and Maddalena's idea of Wittgenstein and particularly of Wittgentein's ethics are quite different, since the former, focusing on the importance of practices and on their primacy above rules, tends to connect directly the ethical dimension with the descriptive one; while the latter affirms that the two dimensions are clearly distinguished both in the early and the later Wittgenstein. Besides, Michele Marsonet and Eva Picardi clearly diverge on the interpretation of Rorty's philosophy on relativism: Marsonet equates Rorty to relativism, while Picardi highlights that it is because Rorty wants to avoid relativism that he espouses (incorrectly, in her view) anti-representationalism. The presence of these differences is, I think, one of the positive qualities of this book, as it shows that the debate is still open and lively. To make pragmatism and analytic philosophy 
interact seems to be a precious means for doing philosophy, that is, to see things from different perspectives in order to get a more complete idea of their meanings.

\section{BIBLIOGRAPHY}

BRANDOM R. B., (1994), Making it Explicit: Reasoning, Representing, and Discursive Commitment, Cambridge (Mass.), Harvard University Press.

CALCATERRA R. M. (ed.), (2006), Pragmatismo e filosofia analitica. Differenze e interazioni, Macerata, Quodlibet.

CAVELl S., (1998), “What's the Use of Calling Emerson a Pragmatist?,” in Dickstein M. (ed.), The Revival of Pragmatism: New Essays on Social Thought, Law \& Culture, Durham (NC), Duke University Press.

DAVIDSON D., (2001), Subjective, Intersubjective, Objective, Oxford, Oxford University Press. DE CARO M., \& D. MACARTHUR (eds), (2004), Naturalism in Question, Cambridge (Mass.), Harvard University Press.

DEWEY J., (1967-90), The Collected Works: 1882-1953, Carbondale-Edwardsville, Southern Illinois University Press.

JAMES W., (1907); Pragmatism: a New Name for Some Old Ways of Thinking, New York/ London, Longmans, Green \& Co.

JAMES W., (1909), The Meaning of Truth: a Sequel to 'Pragmatism,' New York/ London, Longmans, Green \& Co.

MCDOWELl J., (1994), Mind and World, Cambridge (Mass.), Harvard University Press.

PEIRCE C. S., (1931-58), Collected Papers of Charles Sanders Peirce, eds. Hartshorne C. et al., Cambridge (Mass.), Harvard University Press.

PUTNAM H., (1999), The Threefold Cord: Mond, Body and the World, New York, Columbia University

Press.

RORTY R., (1990), "Pragmatism as anti-Representationalism,” introduction to Murphy J.,

Pragmatism: from Peirce to Davidson, Boulder, Westview Press.

RUSSELl B., (1908), “Transatlantic Truth,” The Albany Review 2, 393-410.

RUSSELl B., (1966), “James' Conception of Truth,” in Russell B., Philosophical Essays, revised version, London, George Allen and Unwin.

SCHEMAN N., (1996), "Forms of Life: Mapping the Rough Ground," in Sluga H. \& Stern D. G., (eds.), The Cambridge Companion to Wittgenstein, Cambridge, Cambridge University Press.

SELlars W., (1963), "Empiricism and the Philosophy of Mind," in Sellars W., Science, Perception and Reality, London, Routledge and Kegan Paul. 
WITTGENSTEIN L., (1922), Tractatus logico-philosophicus, English translation by C. K. Ogden, London, Routledge \& Kegan Paul.

WITTGENSTEIN L., (1953), Philosophical Investigations, English translation by G. E. M. Anscombe \& R. Rhees, Oxford, Blackwell.

WitTGenstein L., (1965), “A Lecture on Ethics,” G. E. M. Anscombe et al. (eds.), The Philosophical Review, LXXIV, 3-12.

\section{NOTES}

1. De Caro \& Macarthur 2004.

2. Wittgenstein 1922, 1965.

3. Wittgenstein 1953.

4. Dewey (1967-90, vol. 7: 190-1).

5. Sellars 1963; McDowell refers to the first stage of the myth of Jones, hence to paragraphs XIV and ff.

6. Brandom (1994: 256-7).

7. Cavell 1998, Scheman 1996.

8. McDowell 1994.

9. Peirce (1931-58, vol. 5: 212).

10. Rorty (1990: 3).

11. Davidson (2001: 46).

12. Russell 1908; Russell 1966.

13. Cfr. James (1907: 97).

14. James (1909: 180-216); Putnam (1999: 119).

15. James (1907: 102).

16. Calcaterra 2006.

\section{AUTHORS}

\section{ANNA BONCOMPAGNI}

Università degli Studi di Firenze (University of Florence) anna.boncompagni[at]gmail.com 